\title{
X-RAY STUDY OF MICRO-VOLUME MINERALS IN "KUROKÔ" (BLACK ORE) WITH MICRO DEBYE-SCHERRER CAMERA
}

\author{
-(2) BETECHTINITE FROM THE YOSHINO MINE, \\ YAMAGATA PREFECTURE, JAPAN- \\ NaOYa Imai, Norimichi Watanabe* and Sumio Yamada \\ Department of Mineral Industry, School of Science and Engineering, Waseda University, Tokyo
}

\section{INTRODUCTION}

Betechtinite is a rare sulphide mineral in the system $\mathrm{Cu}-\mathrm{Fe}-\mathrm{Pb}-\mathrm{S}$, having so far only been found to occur at several localities in the world. It was found as a new mineral from the Mansfeld copper deposits, Germany by Schüller and Wohlmann (1955). In Mansfeld, the mineral of acicular form was found in calcite vein cutting the copper shale, and is closely associated with bornite, galena, chalcocite and native silver (Schüller and Wohlmann, 1955; Schüller, 1960).

Since then, the additional occurrence of betechtinite has been recorded from Dzhezkazgan, USSR (Satpayeva, 1959; Mukanov et al., 1960); Mürtschenalp, Switzerland (Bächtiger, 1963); Tsumeb, South-West Africa (Strunz and Tennyson, 1967); Mt. Lyell, Tasmania, Australia (Markham and Ottemann, 1968); Urup, USSR (Kachalovskaya and Khromova, 1970); and from Radka, Bulgaria (Tsonev et al., 1970). In Japan, the first occurrence of betechtinite in "Kurokô" from the Furutobe mine, Akita Prefecture was reported by Matsukuma, and it has been studied in detail (Matsukuma, 1968, 1970, 1971).
During the course of his intensive study on Kurokô deposits of the Yoshino mine, Yamagata Prefecture, one of the present writers (N.W.) has noted an occurrence of micro-volume mineral in the system $\mathrm{Cu}-\mathrm{Fe}$ $\mathrm{Pb}-\mathrm{S}$, corresponding to betechtinite in both optical properties and chemical composition in "Kurokô" (Watanabe, 1971a, b).

The main object of the work reported here was to offer the results of X-ray microdiffraction of the mineral, together with those of electron-probe microanalysis and ore microscopy, and to reveal that the micro-volume mineral in question is identical approximately with betechtinite $\left(\mathrm{Pb}_{2}\right.$ $\left.(\mathrm{Cu}, \mathrm{Fe}){ }_{21} \mathrm{~S}_{15}\right)$ in its mineralogical properties. Brief discussion on some mineralogical problems concerning betechtinite was also given.

\section{Ore SPECIMEN INVESTigated}

In general, "Kurokô" of the Hisaka orebody, from which the present micro-volume mineral was found, is composed of sphalerite, chalcopyrite, pyrite and subordinate galena, with small amounts of tetrahedrite and covellite. However, some fine-grained compact "Kurokô" rich in chalcocite and the unidentified argentiferous copper sul-

\footnotetext{
* Present address: Tômen Co. Ltd., Tokyo (Manuscript received may, 8, 1972).
} 
phide occupying the uppermost portion of "Kurokô" zone of the stratiform part in Hisaka exhibits complex mineral assemblage. In such ores, electrum, idaite, stromeyerite, hematite, bornite and betechtinite are found, though not common. In the present study, the above-mentioned unidentified phase is tentatively designated by the symbol $X$.

The ore specimen containing the microvolume mineral now under investigation (specimen No. 58-2) was taken from the uppermost "Kurokô" zone in stratiform part of the Hisaka orebody in 1964 by Dr. T. Kita. This is a fine-grained compact "Kurokô" with black colour.

\section{Ore Microscopy}

Under the ore microscope, the ore (specimen No. 58-2) is seen to consist mostly of pyrite, sphalerite, $X$ and barite as a gangue, with small amounts of hematite, covellite, electrum, betechtinite and stromeyerite. Among them, $X$ is the most dominant constituent, and it may be distinguished from chalcocite by its lower reflectivity, stronger anisotropism and grayer tints. $X$ matrix contains sphalerite with irregular form and pyrite in colloform intergrowth, in which a core of sphalerite is commonly rimmed by narrow bands of intimately intergrown pyrite. Also, well-rounded colloform sphalerite less than $20 \mu$ in diameter is scattered throughout $X$. In some part of $X$, concentric colloform texture displayed by the colloform bands, usually in the order of $X$ or sphalerite (core) $\rightarrow$ sphalerite or $X \rightarrow$ pyrite from inner to outer, is recognized.

Hematite is rarely found, and occurs as irregularly-shaped flakes up to $100 \mu$ in length, and some of them are embedded in $X$. Lattice intergrowth of covellite and the host bornite is sometimes observed.

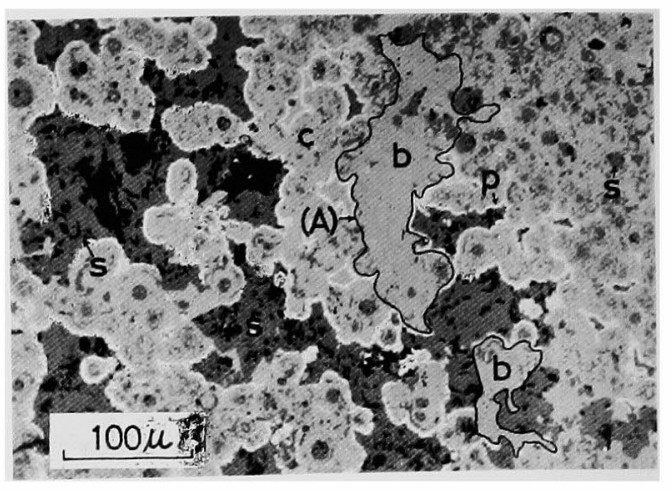

Fig. 1. Photomicrograph of polished section of "Kurokô" from the Yoshino mine, showing the mode of occurrence of betechtinite (specimen No. 58-2).

Polarizer only. b: Betechtinite, c: Unidentified argentiferous copper sulphide $(X)$, p: Pyrite, s: Sphalerite, (A): Grain (A). Black area with irregular shape represents pit.

As shown in Fig. 1, the present betechtinite occurs as grains with elongated and irregular shape, attaining up to $200 \mu$ in longer dimension and it is in direct contact with $X$, sphalerite and pyrite which forms narrow rim of sphalerite. Minute inclusions of colloform sphalerite with well-rounded or irregular form are also found within these grains. In reflected light, the mineral is faintly pleochroic from cream-yellowish gray to gray with brownish tone in air, somewhat enhanced in oil. The reflectivity is approximately identical with that of the associated $X$. Between obliquely crossed nicols, the mineral is strongly anisotropic, without noticeable change in colour, and the anisotropism varies from one grain to others due to the deviation of crystallographic orientation. The polishing and scratching hardnesses are somewhat higher than those of the associated $X$. It readily tarnishes in polished section within a few days.

\section{ELEGTRON-PROBE MigRoANALYSIS}

Electron-probe microanalysis on sever- 
al grains of the present betechtinite, two of which appear in Fig. 1, was performed using an Akashi electron-probe X-ray microanalyzer (EPMA, Tronalyzer, model TRA-25), with $25^{\circ} \mathrm{X}$-ray take-off angle. Operating conditions of EPMA in all measurements were; electron-acceleration voltage: $25 \mathrm{kV}$, probe current: $0.08 \mu \mathrm{A}$, electron impact diameter: $1 \sim 2 \mu$, analyzing crystals used: $\mathrm{LiF}$, mica and PET, and detector: gas (Ar)flow P.C.

Qualitative microanalysis by spectrometer scans served to identify the elements of $\mathrm{Cu}, \mathrm{Fe}, \mathrm{Pb}$ and $\mathrm{S}$ in the mineral, and other elements such as $\mathrm{Ag}$ were less than the detective limit of EPMA. Variation in intensities of characteristic X-rays of $\operatorname{CuK} \alpha$, $\mathrm{FeK} \alpha, \mathrm{PbL} \alpha$ and $\mathrm{SK} \alpha$ obtained by electronprobe traverses confirmed the absence of significant inhomogeneity with respect to the concentration of $\mathrm{Cu}, \mathrm{Fe}, \mathrm{Pb}$ and $\mathrm{S}$ in the phase.

In order to establish the chemical composition of the mineral, quantitative microanalysis was carried out on grain (A) in Fig. 1. Calculation of concentration of $\mathrm{Cu}, \mathrm{Fe}$, $\mathrm{Pb}$ and $\mathrm{S}$ was made from the measured intensity ratio for chosen line in the mineral to that in the standards. Several small prismatic crystals of the Dzhezkazgan be- techtinite kindly provided by Dr. K. Sakurai, were used as micro-probe standards. It was assumed that these crystals have the same chemical composition as that given by Mukanov et al. (1960), which is shown in Table 1 (5). The results are listed in Table 1 , together with those reported in previous papers for comparison. The calculation of the empirical formulae from an analysis on the basis of $S=15.0$ and $S=7.0$ led the following results: $\mathrm{Pb}_{2.1}\left(\mathrm{Cu}_{22.2} \mathrm{Fe}_{1.2}\right)_{23.4} \mathrm{~S}_{15.0}$ and $\mathrm{Pb}_{1,0}\left(\mathrm{Cu}_{10.4} \mathrm{Fe}_{\mathbf{0 . 6}}\right)_{11.0} \mathrm{~S}_{7.0}$, respectively. Obviously, the formula, which alone compatible with the chemical composition of the present betechtinite, is the latter.

\section{X-RAY MIGRODIFFraction}

The X-ray diffraction procedure employed here was virtually identical with that described in a previous paper (Imai et al., 1970). In this study also, Dr. A. Kato kindly cooperated with the present writers, and he performed the troublesome task of sample preparation. It was successful to mount an extremely minute amount of the powder of grain (A) in Fig. 1 on the edge of a glass fiber of about $50 \mu$ diameter, using manicure as a binder under the ore microscope.

Considering advantage for producing

Table 1. Chemical analyses of betechtinite.

\begin{tabular}{l|c|c|c|c|c|c|c}
\hline & $(1)^{*}$ & $(2)^{*}$ & $(3)^{*+}$ & $(4)^{*}$ & $(5)$ & $(6)$ & $(7)$ \\
\hline $\mathrm{Cu}$ & 59.0 & 57.0 & 59.57 & 59.0 & 58.88 & 59.70 & 57.19 \\
$\mathrm{~Pb}$ & 17.9 & 18.0 & 18.01 & 17.3 & 17.47 & 17.33 & 18.65 \\
$\mathrm{Fe}$ & 2.8 & 2.9 & 1.65 & 2.7 & 2.81 & 2.69 & 2.51 \\
$\mathrm{Ag}$ & - & - & - & - & 0.79 & - & - \\
$\mathrm{S}$ & 20.1 & 21.7 & 20.77 & 20.6 & 20.16 & 20.09 & 21.65 \\
Total & 99.8 & 99.6 & 100.00 & 99.6 & 100.11 & 99.81 & 100.00 \\
\hline
\end{tabular}

(1): Betechtinite, Yoshino mine, Japan (the present writers, 1972); (2):-, Furutobe mine, Japan (Matsukuma, 1971); (3):-, Radka, Bulgaria (Tsonev et al., 1970); (4):-, Mt. Lyell, Tasmania, Australia (Markham and Ottemann, 1968); (5):-, Dzhezkazgan, USSR (Mukanov et al., 1960); (6):-, Mansfeld, Germany (Schüller, 1960); (7):-, calculated from the formula $\mathrm{Pb}_{2} \mathrm{Cu}_{20} \mathrm{FeS}_{15}$.

*: The results obtained by electron-probe microanalysis. +: The total $106.97 \%$ was reduced to $100 \%$. 
useful X-ray diffraction halo in a short exposure time, the present writers employed the micro Debye-Scherrer camera of $28.6 \mathrm{~mm}$ diameter connected with microfocus X-ray generator (Microflex, model B-3), made by Rigaku Denki Co., Japan. Operating conditions of microfocus X-ray generator were; Ni-filtered $\mathrm{CuK} \alpha$-radiation $(\lambda=1.5418 \AA$ ), tube voltage: $40 \mathrm{kV}$, tube current: $2.3 \mathrm{~mA}$. The rate of rotation of the sample (glass fiber) was $360^{\circ}$ per minute. The exposures were 5 and 15 hours and film used was of Sakura type N.

$\mathrm{X}$-ray powder photographs of the present material thus taken are shown in Fig. 2. From the figure, it can be seen that smoothing out spotty lines is unsatisfactory due to the considerably large crystallite size of the powder resulting from special way of sample preparation.

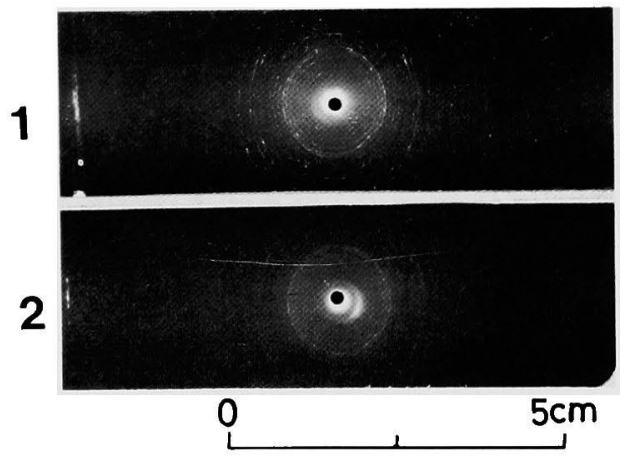

Fig. 2. X-ray powder photographs of betechtinite (grain (A) in Fig. 1) taken by use of micro Debye-Scherrer camera.

1: Exposed for 5 hours, 2: 15 hours (All employing $\mathrm{CuK} \alpha$-radiation).
In Table 2, the observed powder data are tabulated, together with those for betechtinites from Mansfeld and Dzhezkazgan given by Mukanov et al. (1960) and from Radka by Tsonev et al. (1970) for comparison. The camera diameter was calibrated using an extra-pure copper wire $\left(\mathrm{a}_{\mathbf{0}}=3.614_{7}\right.$ $\dot{A})$ of $0.2 \mathrm{~mm}$ diameter as a standard and it was estimated at $28.54 \pm 0.02 \mathrm{~mm}$, but no correction for the errors due to film shrinkage and no refinement were made for the observed $d$-spacings. The relative intensity measurement of diffraction maxima was made from visual estimation under the comparator.

Table 2 shows that the powder data for the present material are in general agreement with those for betechtinites from Mansfeld, Dzhezkazgan and Radka, except for a few reflections unindexed or with considerable deviation in the $d$-spacings, and the data show characteristic and relatively strong reflections, corresponded to the $d$-spacings of $3.1 \dot{\mathrm{A}}, 2.93 \dot{\mathrm{A}}, 2.34 \dot{\mathrm{A}}$ and $1.815 \dot{\mathrm{A}}$.

\section{Discussion and Conclusions}

The ore microscopy of the present material described in foregoing section has shown the approximate identity of the optical properties with the Furutobe betechtinite presented by Matsukuma (1968, 1970, 1971), the Mansfeld betechtinite by Schüller and Wohlmann (1955) and Ramdohr (1969), and with the Dzhezkazgan betechtinite by Mukanov et al. (1960). However, the mineral assemblage of the ore specimen now

Scale of decreasing intensities: vs, s, m, w, vw. (1): Betechtinite, Yoshino mine, Japan (specimen No. 58-2, grain (A) in Fig. 1); (2):-, Dzhezkazgan, USSR; (3):-, Mansfeld, Germany; (4):-, Radka, Bulgaria. Data (2) and (3) were given by Mukanov et al. (1960), and data (4) were by Tsonev et al. (1970). + : Indices on the basis of $a_{0}=2 \times 11.40 \AA, b_{0}=14.67 \AA, c_{0}=3.86 \AA$ (Dornberger-Schiff and Höhne, 1959; Strunz, 1970). *: Relatively strong reflections which were unindexed, but appearing in the X-ray powder diffraction data for betechtinite from Mansfeld given by Schüller and Wohlmann (1955). 
Table 2. Observed X-ray powder diffraction data for betechtinite.

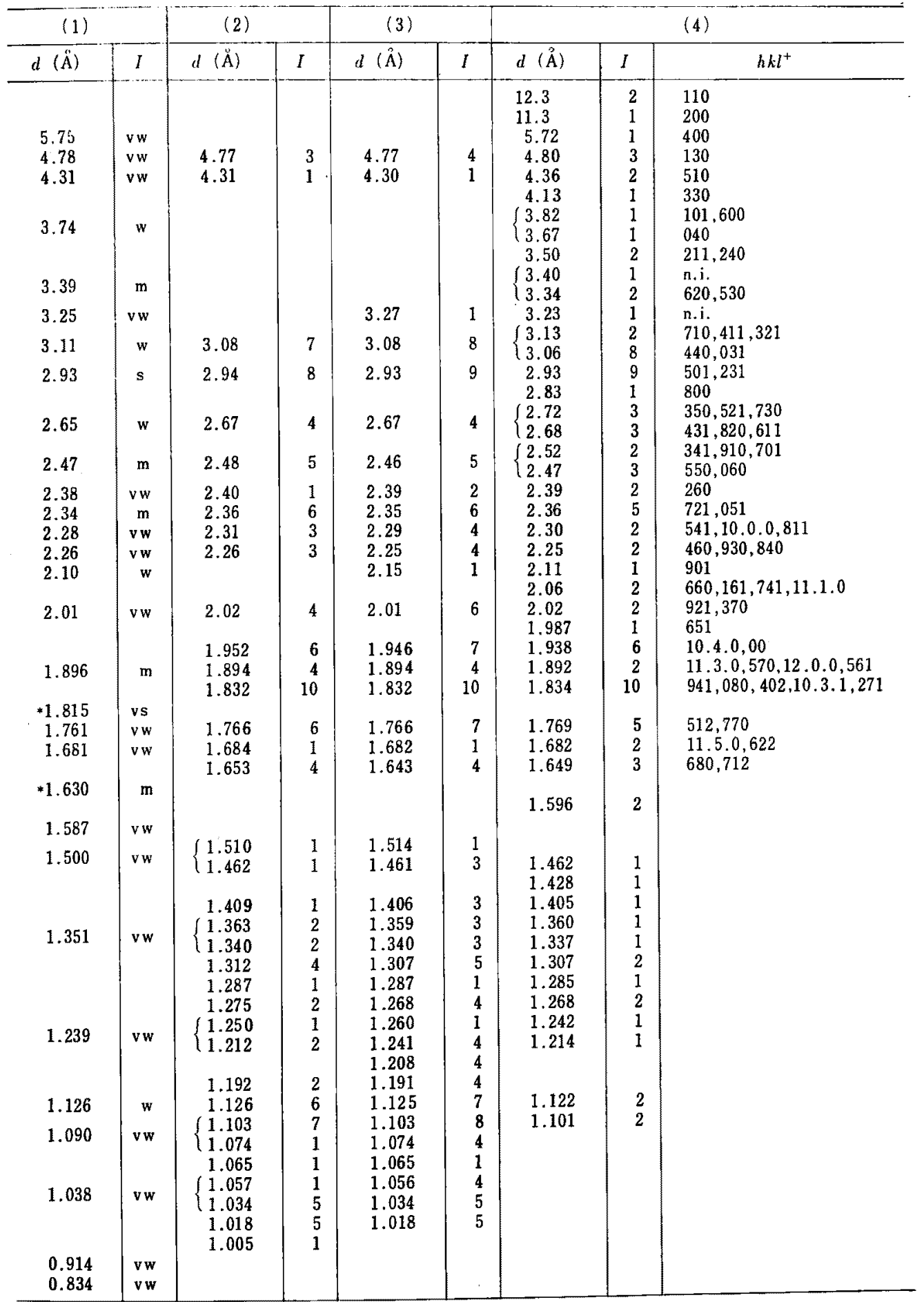


examined, represented by stromeyerite-betechtinite-hematite-pyrite-sphalerite- $X$-barite, is somewhat different from those reported in previous papers, particularly from that of the Furutobe ores (Matsukuma, 1968, 1970, 1971).

In spite of some difference in its mode of occurrence, however, the X-ray powder diffraction data given afore as well as the optical properties and the results of chemical analysis by EPMA presented earlier indicate that the micro-volume mineral in question may be attributed to betechtinite.

Glaring discrepancy between the X-ray powder diffraction data on five betechtinites with different mode of occurrence from Mansfeld was shown by Schüller and Wohlmann (1955), but they did not give any comments about this fact (Fleischer, 1956). Subsequently, the crystal structure of the Mansfeld betechtinite was determined by DornbergerSchiff and Höhne (1959), and they gave the following results; unit-cell dimensions: $a_{0}=$ $3.86 \dot{\mathrm{A}}, \quad b_{0}=14.67 \dot{\mathrm{A}}, \quad c_{0}=22.80 \dot{\mathrm{A}}, \quad$ space group: Immm, cell formula: $\mathrm{Pb}_{2}(\mathrm{Cu}, \mathrm{Fe})_{21}$ $\mathrm{S}_{15}, Z \cong 2$. However, it must be remembered here that indexing of the resolved peaks in the X-ray diffraction patterns of all betechtinites is not always possible on the basis of the above-mentioned unit-cell dimensions and the space group.

As shown in Table 2, in the case of the present material, the powder data are approximately identical with those for betechtinites from Mansfeld and Dzhezkazgan given by Mukanov et al. (1960), and from Radka by Tsonev et al. (1970). However, the position of a strong reflection, corresponded to a $d$-spacing of $1.815 \AA$ appearing in the $\mathrm{X}$-ray diffraction pattern of the present material shifts considerably from that of the strong reflection at $1.832 \dot{\mathrm{A}}$ by Mukanov et al. (1960). Also, the unindexed reflection at $1.630 \AA$ is observed as relatively strong line, as shown in Table 2 (1). It is a noticeable fact that the $1.815 \dot{\mathrm{A}}$ and 1.634 $\dot{A}$ reflections appeared as intense lines in one of the powder data (No. 6) for the Mansfeld betechtinites given by Schüller and Wohlmann (1955), and Ramdohr (1969) stated that the $1.815 \dot{\mathrm{A}}$ reflection is a criterion in the identification of betechtinite.

Inconsistencies to some extent in the $\mathrm{X}$-ray diffraction patterns as mentioned above as well as the considerable deviation from the chemical composition of betechtinites expected from the formula $\mathrm{Pb}_{2}(\mathrm{Cu}$, $\mathrm{Fe})_{21} \mathrm{~S}_{15}$ as revealed by previous workers suggested that there remain some mineralogical problems as to betechtinite itself. It is worthy to note that the empirical formula calculated from chemical analysis of the present material corresponds closely to $\mathrm{Pb}(\mathrm{Cu}, \mathrm{Fe})_{11} \mathrm{~S}_{7}$ which was already quoted for betechtinite from Dzhezkazgan by Mukanov et al. (1960). Further investigation of this mineral seems desirable (Fleischer, 1956).

Quite recently, it was successful to take the X-ray powder photographs of the present sample with standard Debye-Scherrer camera of $57.3 \mathrm{~mm}$ diameter using Fe-filtered $\mathrm{CoK} \alpha$-radiation and $\operatorname{CoK} \alpha_{1}$-radiation obtained by use of monochromator ( $\mathrm{LiF}, 2 d_{200}$ $=4.028 \AA$ ). It was confirmed that the powder data in Table 2 (1) stand comparison with those obtained by the above $\mathrm{X}$-ray diffraction procedure in preciseness of the observed $d$-spacings.

In the present study also, it has been revealed that the application of micro Debye-Scherrer camera in conjunction with microfocus $\mathrm{X}$-ray generator to the microvolume minerals is an outstanding performance for the phase identification of them. 


\section{AGKNOWLEDGEMENTS}

The writers would like to offer their sincere thanks to Professors T. Watanabe and T. Matsukuma of Akita University for helpful adivce and the critical reading of the manuscript, and to Dr. A. Kato of the National Science Museum, Tokyo for his skilled technical assistance and kind advice. Their heartfelt gratitudes are expressed herewith to Dr. T. Kita of Geological Survey of Japan (now at the Ote Exploitation Co.) for his kind gift of ore specimens from the Yoshino mine, Dr. K. Sakurai of the National Science Museum for his generous donating of the betechtinite crystals from Dzhezkazgan, and to Dr. Yoshimatsu and Mr. S. Takahashi of Rigaku Denki Co. for kind cooperation in the course of $\mathrm{X}$-ray study. The writers are greatly indebted to Associate Professor T. Nakamura of Waseda University for his skilled technical assistance during the course of electron microprobe study.

Finally, the writers wish to acknowledge partial financial support by Grant-inAid for Fundamental Scientific Research from the Ministry of Education of Japan, which facilitated the present work.

\section{REFERENCES}

Bächtiger, K. (1963), Die Kupfer- und Uranmineralisation der Mürtschenalp, Beitr. Greol. Schweiz, Geotech., Ser. 38, 113.

Dornberger-Schiff, K. und Höhne, E. (1959), Die Kristallstruktur des Betechtinit $\mathrm{Pb}_{2}(\mathrm{Cu}, \mathrm{Fe})_{21}$ $\mathrm{S}_{15}$, Acta Cryst., 12, 646-651.

Fleischer, M. (1956), New mineral name (betekhtinite), Amer. Miner., 41, 371-372.

Imai, N., Watanabe, N. and Takahashi, S. (1970), $\mathrm{X}$-ray study of micro-volume minerals in "Kurokô" (Black ore) with micro DebyeScherrer camera - (1) Aikinite from the Kurosawa mine, Fukushima Prefecture, Japan, Jour. Japan. Assoc. Miner. Pet. Eco. Geol., 64, 149-156.
Kachalovskaya, V.M. and Khromova, M.M. (1970), Betekhtinite, hessite, and stromeyerite in bornite ores from the Urup deposit (in Russ.), Geol. Rud. Mestorozhd., 12 (1), 93-97; Chem. Abst., 72 (26), $135001 \mathrm{~h}$ (1970).

Markham, N.L. and Ottemann, J. (1968), Betekhtinite from Mt. Lyell Tasmania, Miner. Deposita, 3, 171-173.

Matsukuma, T. (1968), On the betechtinite from the Furutobe Mine (abst. in Japan.), Preliminary Note of Joint Meeting of MSJ, SMGJ and JAMPEG, held in Okayama, 19.

Matsukuma, T. (1970), Betechtinite from the Kuroko deposits of the Furutobe mine, Akita Prefecture, Japan, Coll. Abst., IMA-IAGOD Meeting '70, Tokyo-Kyoto, 200.

(1971), Betechtinite from the Kuroko deposits of the Furutobe mine, Akita Prefecture, Japan, Miner. Soc. Jap., Spec. Pap. 1 (Proc. IMA-IAGOD Meeting '70, IMA Vol.), 191-195.

Mukanov, K.M., Narkelyun, L.F. and Yakovlevskaya, T.A. (1960), On the occurrence of betekhtinite in the Dzhezkazgan ore deposit, Dolklady Acad. Sci., USSR, 130, 133-135 (translated from: O Nakhodke Betekhtinita na Dzhezkazganskom Mestorozhdenii, Doklady Akademii Nauk, SSSR, 130 (2), 404-407, 1960).

Ramdohr, P. (1969), The ore minerals and their intergrowth, Pergamon Press, New York, 481482 .

Satpayeva, T.A. (1959), Betekhtinite from the Dzhezkazgan ore deposit (in Russ.), Izv. Akad. Nauk Kaz., SSR, 1, 95-103.

Schüller, A. und Wohlmann, E. (1955), Betechtinit, ein neues Blei-Kupfer-Sulfid aus den Mansfelder Rücken, Geologie, 4, 535-555.

Schüller, A. (1960), Zur Kenntnis des Betechtinit, $(\mathrm{Cu}, \mathrm{Fe})_{10} \mathrm{PbS}_{>6}$, Neues Jahrb. Miner. Monatsh., 121-131.

Strunz, H. und Tennyson, Ch. (1967), Schaurteit, ein neues Germanium-Mineral von Tsumeb, S/W Afrika und seine Paragenese, Festschrift Dr. Werner T. Schaurte, 33-47.

Strunz, H. (1970), Mineralogische Tabellen, Leipzig, 144 .

Tsonev, D., Bonev, I. and Terziev, G. (1970), Betekhtinite from the Radka deposit (in Russ. with English abst.), Bull. Geol. Inst., Series Geochem. Miner. Petrogr., Bulgarian Acad. Sci., $X I X, 167-177$.

Watanabe, N. (197la), On the Kurokô ores from the Yoshino mine, Yamagata Prefecture, Japan (abst. in Japan.), Mining Geol., 21 (1), 38.

Watanabe, N. (1971b), Neogene Tertiary system in the environs of Yonezawa Basin, and the asso- 
ciated Kurokô deposits (in Japan.), Ph. D. Thesis submitted to the Post-Graduate School of Sci. and Eng'ng., Waseda Univ. (limited print), 1-141.

\section{マイクロ・デバイーシェラー・カメラによる黒鉱に含まれる微小鉱物の $\mathrm{X}$ 線的研究}

\section{(2) 山形県吉野鉱山産ベテフチン鉱}

今井 直哉・渡辺 則道・山田 純男

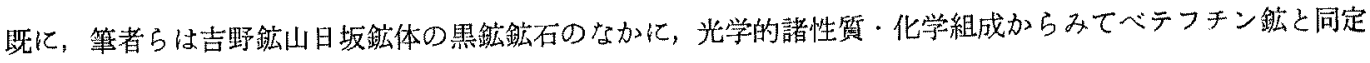
できる微小な $\mathrm{Cu}-\mathrm{Fe}-\mathrm{Pb}-\mathrm{S}$ 系鉱物を認めた。

このたび，そのX 線的研究を企図し，微焦点 X 線発生装置にとりつけられたマイクロ・デバイーシェラー． カメラ $(28.6 \mathrm{~mm} \phi)$ によりその微量粉末のX 線回折写真の撮影に成功した。得られた粉末データと Mansfeld, Dzhezkazgan および Radka 産ベテフチン鉱のそれらとの間䎲は，2.3の回折線を除いてかなり良好な一致か認 められ，との鉣物をベテフチン鉱とみてまず間違いのないととが判っだ。

けれども，てれまでに報告されたべテフチン鉱のX線粉末データに認められるかなりいらじるいい不一致は， その化学組成が理想式から期待される值よりかなり偏倚する事実と相まって，との鉱物についてさらに检討すべ きととを暗示している。 